\title{
THE DEVELOPMENT OF ANEUPLOIDY IN SOMATIC CELLS OF EXPERIMENTALLY PRODUCED TRIPLOID LARCHES
}

\author{
ZOE MARIA ILLIES \\ Federal Research Organisation for Forestry and Forest Products, Institute for Forest Genetics \\ and Tree Breeding, Schmalenbeck, Germany
}

Received 8.xi.65

\section{INTRODUCTION}

IN 1956 colchicine-treated 7-year-old larches flowered for the first time and were crossed reciprocally with untreated diploid larches. Chromosome counts in the root tips of the products revealed the presence of diploid $(2 n=24)$, polyploid and aneuploid seedlings with variable chromosome numbers within the diploid to triploid range.

Over the next 2 years, supplementary chromosome counts in needle buds showed that some of the individuals originally classified as triploids were, or became, chimaeras. Forty seedlings which proved to be triploid in both the root and bud counts were retained.

In I 964 the chromosome numbers in these 40 selected "triploids" were again checked. These too have now proved to be unstable with counts ranging from the triploid to the diploid level like those of the original chimaeral class. This paper presents a more detailed account of the development of aneuploidy.

\section{MATERIAL AND METHODS}

The parental trees were, with one exception, either Larix decidua Mill, or L. leptolepis Sieb. and Zucc. They were raised from certificated, non-indigenous, forest stands in North-West Germany. They are therefore a heterogeneous group. Hybrids of $L$. decidua and $L$. leptolepis are common in nature and the exceptional parental tree ( $L$. eurolepis in the tables $=L$. decidua $\times L$. leptolepis) was such a hybrid. The stem apex of these seedlings had been treated with 0.5 per cent. colchicine during the I4 days immediately after the seed coat was shed. The successfully treated plants were selected during the first year after treatment. They have been under cytological observation since, and were found to remain chimaeral (Illies, 1957). The colchicineinduced generation will be called $C_{0}$ and their progenies $C_{1}$.

Details of colchicine treatment have been described elsewhere (Illies, 195I). All cytological observations of the parent trees were made on needle bases and those of the offspring on root-tips immediately after germination. The aceto-carmine squash technique was used in both cases.

For subsequent chromosome counts the best source of mitosis was in young needle buds, either in September from needle initials, or in spring before flushing. The spring material was obtained from branches brought into the greenhouse in late winter and given supplementary light for 16 hours daily while maintaining high humidity. After some days, before differentiation of the meristem had taken place, dividing cells were available. As the season proceeded, the time needed to force the buds became shorter, beginning with 3-4 days in January. The excised needles were pretreated with I per cent colchicine for 5 hours in the light. After fixation in acetic alcohol $(\mathrm{r}: 3)$, the tissue was stained in aceto-carmine in small tubes placed in a water bath until it started to boil. Permanent slides were prepared by the method of Darlington and La Cour (1960, Sch. 2'). 


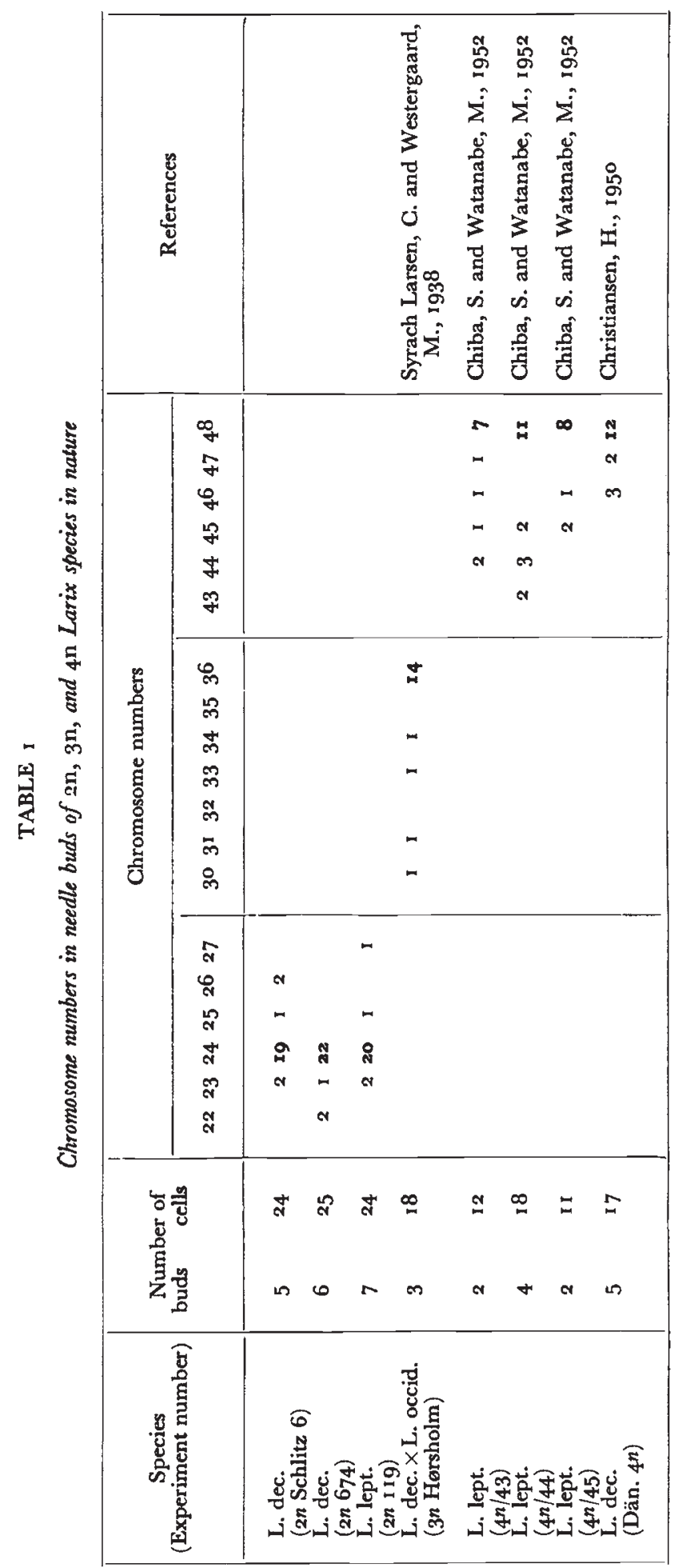




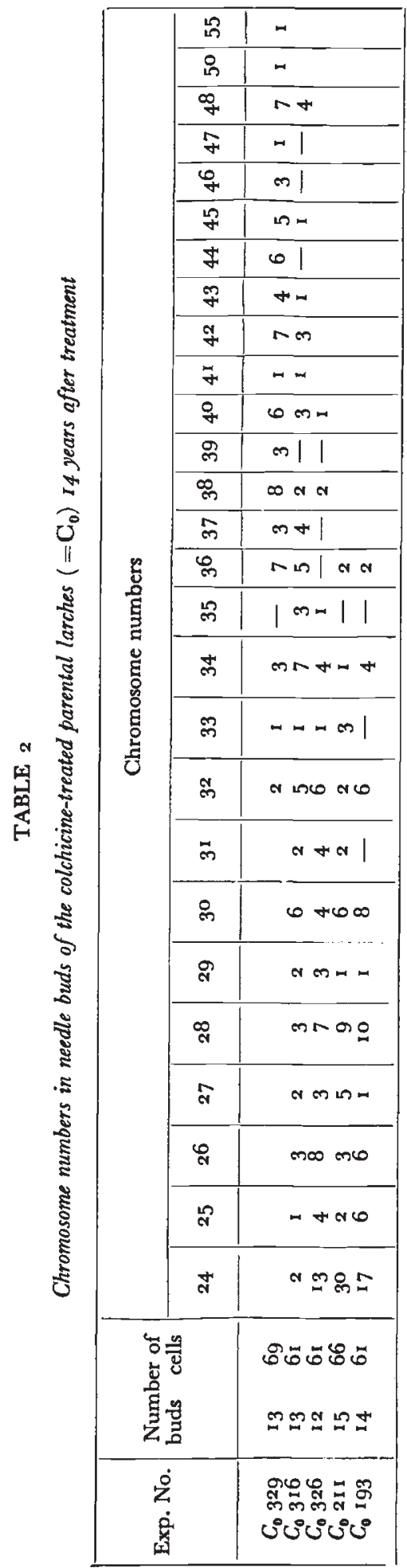




\section{RESULTS}

Various workers have observed naturally occurring polyploidy in the Pinaceae. In some cases variable chromosome numbers in the

TABLE 3

Results of reciprocal crosses between colchicine-treated larch $\left(=\mathrm{C}_{0}\right)$ and $2 n$ larch

\begin{tabular}{|c|c|c|c|c|c|c|c|c|c|}
\hline \multirow{4}{*}{$\begin{array}{c}\text { Crosses } \\
\text { (Exp. Nos. and Species) }\end{array}$} & \multicolumn{3}{|c|}{ a } & \multirow{2}{*}{\multicolumn{6}{|c|}{$\begin{array}{c}\mathrm{b} \\
\text { Seedlings }\end{array}$}} \\
\hline & \multicolumn{2}{|c|}{ Number of } & \multirow{3}{*}{ 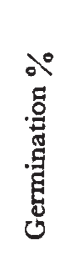 } & & & & & & \\
\hline & \multirow{2}{*}{ 总 } & \multirow{2}{*}{ 总 } & & \multicolumn{2}{|c|}{ Diploids } & \multicolumn{2}{|c|}{ Triploids } & \multicolumn{2}{|c|}{$\begin{array}{l}\text { Aneu- } \\
\text { ploids }\end{array}$} \\
\hline & & & & No. & $\%$ & No. & $\%$ & No. & $\%$ \\
\hline \multirow{8}{*}{ 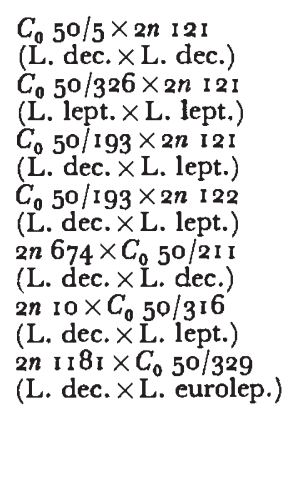 } & I 33 & II & $8 \cdot 3$ & Io & $9^{1} \cdot 0$ & I & $9 \cdot 0$ & - & - \\
\hline & & $\mathrm{I}, 86 \mathrm{I}$ & $17 \cdot 8$ & $\mathrm{I}, 804$ & $97^{\circ} 0$ & I9 & $I \cdot 0$ & $3^{8}$ & $2 \cdot 0$ \\
\hline & 716 & 100 & I3.9 & $9^{1}$ & $9^{1} \cdot 0$ & 7 & $7 \cdot 0$ & 2 & $2 \cdot 0$ \\
\hline & 245 & 35 & $10 \cdot 2$ & 34 & $97 \cdot 2$ & I & $2 \cdot 8$ & - & - \\
\hline & 4,092 & $1,34^{6}$ & $3^{2} \cdot 9$ & $\mathrm{I}, 3 \mathrm{I} 6$ & $97 \cdot 8$ & I6 & $I \cdot 2$ & 14 & $I \cdot O$ \\
\hline & I 39 & 45 & $32 \cdot 4$ & 44 & $97 \cdot 8$ & I & $2 \cdot 2$ & - & - \\
\hline & 18,876 & 2 & 0.01 & - & - & 2 & roo & - & - \\
\hline & & & & & & 47 & & 54 & \\
\hline
\end{tabular}

TABLE 4

Chromosome number in somatic tissue of six trees in 8-year -old triploid larch progenies $\left(=\mathrm{C}_{1}\right)$ from crosses between diploids and colchicine-treated parents $\left(=\mathrm{C}_{0}\right)$

\begin{tabular}{|c|c|c|c|c|c|c|c|c|c|c|c|c|c|c|c|c|c|c|}
\hline \multirow{2}{*}{$\begin{array}{l}C_{1} \text { Exp. } \\
\text { Nos. }\end{array}$} & \multirow{2}{*}{ Origin } & \multirow{2}{*}{\multicolumn{2}{|c|}{$\begin{array}{l}\text { Number of } \\
\text { buds cells }\end{array}$}} & & & & & & & & & & & & & & & \\
\hline & & & & 18 & 19 & 20 & 2 & 2 & & 23 & 24 & 25 & 26 & 2 & 2 & & 29 & 30 \\
\hline$C_{15} 6 / \mathrm{I}$ & $2 n \operatorname{II} 8 \mathrm{I} \times C_{0} 50 / 329$ & 6 & 104 & & & & I & $\varepsilon$ & & 3 & $5^{\circ}$ & 9 & 7 & 4 & & & I & 3 \\
\hline$C_{15} 6 / 3$ & $\begin{array}{l}2 n 674 \times C_{0} 50 / 211 \\
(\text { L. dec } \times \text { L. dec.) }\end{array}$ & 7 & 129 & & & & & & & & I & 一 & & 7 & & & I & 8 \\
\hline$C_{2} 56 / 5$ & 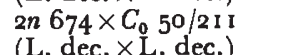 & 8 & 100 & & & & & & & & ro & I & 6 & 3 & I & & 8 & 20 \\
\hline$C_{2} 56 / 3^{826}$ & $\begin{array}{l}2 n \text { Io } \times C_{0} 50 / 316 \\
\text { (L. dec. } \times \text { L. lept.) }\end{array}$ & I 6 & 172 & I & $\mathbf{I}$ & 4 & 5 & $\varepsilon$ & & 5 & 55 & 6 & II & 6 & & & 9 & 7 \\
\hline$C_{256 / 2653}$ & $C_{0} 50 / 326 \times 2 n$ I2I & 8 & 93 & & & & & & & & & & & & & & & $\mathrm{I}$ \\
\hline$C_{1} 56 / 43^{18}$ & $\begin{array}{l}C_{0} 50 / 193 \times 2 n \text { i } 22 \\
(\mathrm{~L} . \text { dec. } \times \text { L. lept. })\end{array}$ & 8 & 93 & & & & & & & & & & & & & & $y$ & 1 \\
\hline
\end{tabular}


somatic tissue of one and the same plant were noticed, but mostly pure triploid or tetraploid plants have been described (Mergen, 1958). My data obtained from vegetatively propagated material of triploid and tetraploid larches found in nature as well as from diploid plants are given in table $\mathbf{I}$.

After colchicine treatment of diploid larches the chromosome numbers vary from tetraploid (48) down to diploid (24) (table 2). Chromosome numbers obtained from the offspring of intra- and interspecific crosses of colchicine-treated and untreated diploids are given in table 3. The data were obtained from root tips in 1956 . Subsequent counts in vegetative buds of the 47 triploids during 1957 and 1958 proved that 40 were relatively stable. Only on rare occasions were aneuploid cells observed. Their frequency fell within the limits set by naturally occurring individuals.

These 40 triploid plants were propagated vegetatively. In 1964 , a routine chromosome recount on the needle buds of the scions as well as on the original trees revealed a greatly increased number of aneuploid cells in contrast with previous years. Six plants have been extensively examined (table 4). In three cases the trend is towards higher numbers of chromosomes while in the others it is towards a lower chromosome number, as in naturally occurring polyploids. However, in the experimental material the frequency and range of aneuploid cell types exceeds the natural spectrum of somatic variation. The unstable triploids and the aneuploids identified in the seedling stage are alike in this respect. There are evident differences in the spread of aneuploid cell types amongst the six individuals examined.

Multipolar spindles have been observed in some triploid plants. This suggests one mechanism which may be responsible for the origin of aneuploid cells. On the other hand it may be a result rather than a cause of numerically unbalanced chromosome sets.

Simak (1962, 1964) has identified two karyotypes in larch species. One type, of which $L$. decidua is representative, has six iso-brachial and

Chromosome numbers

\begin{tabular}{|c|c|c|c|c|c|c|c|c|c|c|c|c|c|c|c|c|c|c|c|c|}
\hline 2 & 33 & 34 & 35 & $3^{6}$ & 37 & 38 & 39 & $4^{\circ}$ & $4^{I}$ & $4^{2}$ & 43 & 44 & 45 & $4^{6}$ & 47 & $4^{8}$ & 49 & 50 & $5 \mathrm{I}$ & 52 \\
\hline I & - & 2 & - & I & & & & & & & & & & & & & & & & \\
\hline $\mathbf{j}$ & 3 & 4 & 9 & 26 & 5 & 3 & 6 & 4 & 2 & 7 & 6 & 3 & I & 7 & 7 & 10 & - & - & $\mathbf{I}$ & 2 \\
\hline 0 & 3 & 8 & I & 7 & - & 2 & - & I & - & I & & & & & & & & & & \\
\hline 4 & 2 & 3 & - & 15 & - & I & & & & & & & & & & & & & & \\
\hline 4 & $\mathbf{I}$ & 1 & 2 & $2 x$ & 4 & 8 & 7 & 1 & 2 & 8 & 3 & 4 & I & 4 & 4 & 13 & 1 & 3 & & \\
\hline I & 3 & 4 & $\mathbf{I}$ & 12 & 2 & 4 & 2 & 4 & 2 & 4 & I & 9 & 5 & 6 & 8 & 10 & 4 & 6 & - & 2 \\
\hline
\end{tabular}


six hetero-brachial chromosome pairs. The former are longer but the differences in lengths within the two groups are insufficient for purposes of chromosome identification. Three chromosome pairs however are distinct from the rest and from each other on account of their secondary constrictions. The second karyotype described by Simak in Siberian Larch is characterised by only two chromosome pairs with secondary constrictions. My own observations indicate that L. leptolepis is of this type. It may therefore be possible to determine to some extent whether particular chromsomes are lost more frequently than others during the formation of aneuploid cells.

\section{SUMMARY}

I. Progenies have been raised from intra- and inter-specific crosses of Larix decidua and L. leptolepis. In each case one of the parents was a colchicine-induced polyploid.

2. Initially, the progenies were of three kinds, diploids, triploids and aneuploid chimaeras with chromosome numbers ranging from the triploid to the diploid level.

3. Latent instability of the original triploid seedlings has been expressed over a period of 6 years. They now have a high frequency of aneuploid cells with a wide distribution of chromosome numbers from $2 n$ to $4 n$.

4. The experimentally induced triploids and chimaeras have a higher frequency of aneuploid cells with a wider range of chromosome numbers than naturally occurring polyploids.

5. Multipolar spindles occur in the induced polyploids which may be a cause of numerical unbalance or the result of genetic unbalance.

Acknowledgments.-During the course of this work the author spent 3 months in the Botany Department, Oxford. I wish to thank Prof. C. D. Darlington for the facilities provided and Dr Leslie $\mathbf{K}$. Crowe for her assistance with the manuscript. I also acknowledge a grant from OECD which made the visit possible.

\section{REFERENCES}

Chiba, S., and WATANabe, $M$. 1952. Tetraploids of Larix Kaempferi in the Nurseries. Bull. Gov. For. Exp. Sta. No. 57, Tokyo, 187-199.

Ghristiansen, H. 1950. A tetraploid Larix decidua Miller. Det Kgl. Danske Videnskab. Selskab. Biol. Meddel., XVIII (9).

ILlies, z. м. 1951. Colchicinversuche an Larix decidua Mill. und Picea abies (L.) Karst. Z. Forstgenetik, I, 36-39.

ILLIEs, z. м. 1957. Cytologische Beobachtungen an einer 7 jährigen $C_{0}$ Generation von Lärche. (Kurzbericht). Silvae Genetica, 6, 151-152.

Mergen, F. 1958. Natural polyploidy in Slash Pine. For. Science, 4, 283-295. (More references cited). 
simak, м. 1962. Karyotype analysis of Larix decidua Mill. from different provenances. Medd. Sta. skogsforskn. Inst., 5I, 3-22.

simak, м. 1964. Karyotype analysis of Siberian larch (Larix siberica Ledb. and Larix sukaczewii Dyl.). Studia Forestalia Suecica, Stockholm Nr. 17, I-1 5 .

SYRACH LARSEN, C., AND WESTERGAARD, M. 1938. A triploid hybrid between Larix decidua Mill. and Larix occidentalis N. M. Journ. Genet., 36, 523-530. 